\title{
Historiese teologie in 'n veranderende konteks
}

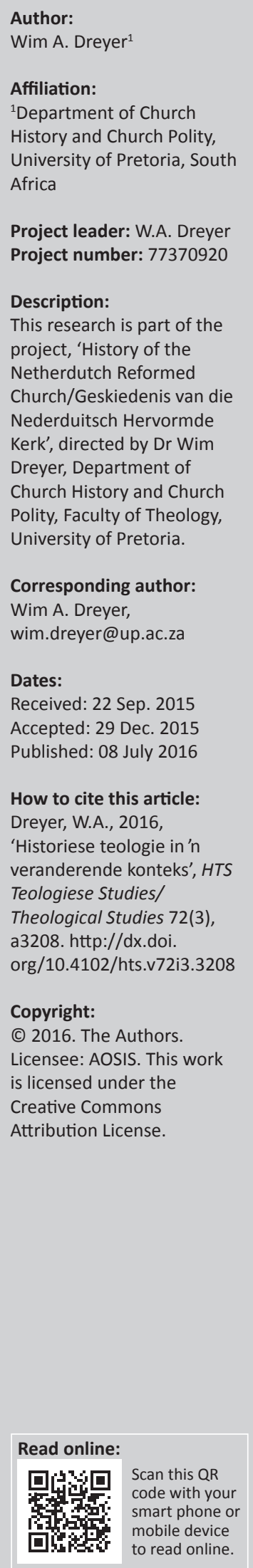

In this contribution, the author reflects on historical theology as theological discipline. After a short introduction to the precarious situation of church history as a theological discipline in South Africa and the question of faith and history, the contribution presents an analysis of Gerhard Ebeling's 1947 publication on church history in which he proposed that church history should be understood as a history of Biblical interpretation. Based on some of the principles Ebeling delineated, the author proposes that historical theology could be applied to five areas of research: prolegomena, history of the church, history of missions, history of theology and church polity. The point is made that historical theology, when properly structured and presented, could play a major role in enriching the theological and ecclesial conversation and in assisting the church in the process of reformation and transformation.

\section{Inleiding}

Suid-Afrikaanse universiteite en teologiese fakulteite is die afgelope jare besig met ingrypende transformasie en herstrukturering. Teen dié agtergrond is kerkgeskiedenis onder groot druk en het dit in verskeie fakulteite alreeds deel geword van groter vakgroeperings.

In hierdie bydrae word voorgestel dat die ou en bekende naam 'historiese teologie' ${ }^{1}$ weer benut en met nuwe inhoud gevul word. Daarteen kan ook besware wees, aangesien historiese teologie, veral in die Duitse wêreld onder invloed van Adolf von Harnack, as Dogmengeschichte (Afrikaans: dogmengeskiedenis) verstaan word (McGrath 2013:10). Tog wil ek dit as sambreel-term voorstel omdat die tradisionele benadering tot kerkgeskiedenis vir alle praktiese doeleindes nie meer aan Suid-Afrikaanse universiteite bestaan nie.

Die keuse vir die term 'historiese teologie' berus onder andere op die insigte en benadering van Geoffrey W. Bromiley (1978:xxi-xxix) en Alister E. McGrath (2001:xxii-xxiv; 2013:1-15). Gerhard Ebeling (1947:10) gebruik ook die term Geschichtstheologie. Dit is opmerklik dat Ebeling, Bromiley en McGrath in baie opsigte by Karl Barth se verstaan van die teologie aansluiting vind. McGrath verwys ook met instemming na Schleiermacher wat reeds in 1811 onderskeid getref het tussen filosofiese teologie, historiese teologie en praktiese teologie. Ook Ebeling (1947:6-9; 1954:5-6) was van mening dat teologie-as-wetenskap uit eksegese (hermeneutiek), historiese teologie, sistematiese teologie en praktiese teologie bestaan.

'n Mens moet ook Wolfhart Pannenberg se verstaan van historiese teologie in gedagte hou (sien Van Huyssteen 1970:76-133). Pannenberg beskou geskiedenis as die mees omvattende horison van die teologie. Omdat die mens wesenlik geskiedenis is, kan hy God slegs in die geskiedenis ontmoet. God openbaar Homself in die geskiedenis, in Jesus Christus wat in die 'volheid van die tyd' mens geword het. Pannenberg verstaan die werklikheid histories vanuit die openbaring van God (Van Huyssteen 1970:77).

Historiese teologie en kerkgeskiedenis is natuurlik nie identies nie. McGrath (2013:8-12) toon egter oortuigend aan dat daar ' $n$ wesenlike interafhanklikheid en wisselwerking tussen historiese teologie, kerkgeskiedenis en dogmengeskiedenis bestaan. Persoonlik verstaan ek historiese teologie meer omvattend, met kerkgeskiedenis en dogmengeskiedenis as onderafdelings. Ek sou ook voorstel dat eerder van 'teologiegeskiedenis' as van 'dogmengeskiedenis' gepraat word daarop word later uitgebrei.

Die interafhanklikheid van teologiese dissiplines is ' $n$ saak wat toenemend aandag geniet. Daar is 'n groeiende tendens en behoefte om bepaalde teologiese temas op 'n multidissiplinêre wyse te benader. Gerhard Ebeling het al kort na die Tweede Wêreldoorlog gepleit vir meer gesprek en

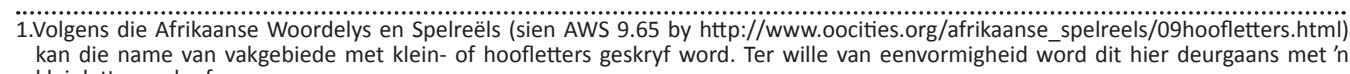
kleinletter geskryf. 
integrasie tussen die verskillende teologiese dissiplines. Hy was oortuig van die interafhanklikheid van die verskillende teologiese dissiplines, veral ten opsigte van historiese teologie en sistematiese teologie. Hy het die onderskeid tussen die verskillende teologiese dissiplines as 'ontoereikend' beskou (Ebeling 1954:6). Ebeling vind die gemeenskaplikheid tussen die verskillende teologiese dissiplines daarin dat alle teologiese arbeid op die uitleg van die Heilige Skrif berus.

In die lig van bogenoemde en die herstrukturering van teologiese dissiplines en fakulteite wat tans in Suid-Afrika plaasvind, sou dit moontlik wees om teologie in ses dissiplines te organiseer:

- hermeneutiek (insluitend Ou- en Nuwe-Testamentiese studies)

- sistematiese teologie (insluitend dogmatiek en etiek)

- historiese teologie

- praktiese teologie

- missionale teologie

- godsdienskunde.

Dit sou ook verminder kon word tot vier departemente, te wete:

- hermeneutiek

- historiese en sistematiese teologie

- praktiese en missionale teologie

- godsdienskunde.

Benewens die uitdagings waarmee veranderende maatskaplike en universitêre werklikhede alle teologiese dissiplines konfronteer, is daar ook 'interne' oorsake waarom spesifiek kerkgeskiedenis onder druk verkeer. Denis (1997) beskryf dit soos volg:

In South Africa, church history is an isolated discipline, almost completely cut off from the social sciences and from secular history in particular. Its academic status can be described as weak. (bl. 84)

Hy is van mening dat kerkhistorici self verantwoordelik is vir die swak posisie van kerkgeskiedenis. Dit word te Eurosentries en kerkspesifiek aangebied. Volgens Denis is kerkhistorici nie goed genoeg onderlê in historiografiese beginsels nie (sien in die verband ook Van Jaarsveld 1953) en hou hulle nie genoegsaam rekening met ander vakwetenskappe nie. Die kritiek van Denis is voorheen deur Maluleke (1995) verwoord in ' $n$ doktorale proefskrif waarin hy aantoon dat die stem van inheemse kerke in SuidAfrikaanse sendinggeskiedenis tot stilswye gedwing is, veral vanweë ideologiese redes.

Black (2014) is verder van mening dat daar in Suid-Afrika ' $n$ algemene persepsie bestaan dat geskiedenis-as-wetenskap onbelangrik is. In die Nasionale Departement van Onderwys het die beskouing posgevat dat geskiedenis ' $\mathrm{n}$ dustbin subject is (Black 2014:360) ${ }^{2}$ en dat skole nie nodig het om dit verder as Graad 9 aan te bied nie, 'n standpunt wat tans weer 2.Alexander Black het omvangryke navorsing gedoen oor die stand van geskiedenis as skoolvak in Suid-Afrika. hersien word. Swak onderwysers, 'n oninteressante kurrikulum en die klem op wiskunde en natuurwetenskap lei daartoe dat min leerlinge geskiedenis as matriekvak wil neem. Daarbenewens het leerlinge ' $n$ apatiese houding teenoor die verlede (Black 2014:361). Dit beteken dat studente met kerkgeskiedenis begin terwyl hulle oor min historiese kennis, insig of belangstelling beskik.

'n Laaste rede waarom kerkgeskiedenis gemarginaliseer word, is die suspisie waarmee kerkhistorici bejeën word. Sommige kerkhistorici se apologetiese en ideologiese omgaan met die verlede het bygedra tot kerklike verdeeldheid, eksklusivisme en die teologiese begronding van apartheid.

Hierdie bydrae besin oor die aard, inhoud en belang van historiese teologie. Daar word onder andere na Gerhard Ebeling se Kirchengeschichte als Geschichte der Auslegung der Heiligen Schrift (Ebeling 1947) verwys. Daarmee word nie te kenne gegee dat Ebeling die laaste woord oor historiese teologie en kerkgeskiedenis gespreek het nie. Sedert 1947 is historiese teologie en kerkgeskiedenis op verskillende maniere benader (vgl. Denis 1997; Gonzàlez 2002; Vosloo 2009).

Dit is opvallend dat Ebeling min invloed op historiese teologie en kerkgeskiedenis in Suid-Afrika uitgeoefen het. In hermeneutiek en praktiese teologie word gereeld na Ebeling en die sogenaamde 'nuwe hermeneutiek' en 'nuwe homiletiek' verwys (sien Pieterse 1979). Kerkhistorici verwys in die algemeen net in die verbygaan na Ebeling. Ek noem enkele voorbeelde:

- J.A.A.A. Stoop (1978:112) verwys in een paragraaf na Ebeling se benadering tot die kerkgeskiedenis met die waarskuwing dat dit die vakgebied kan reduseer tot 'n studie oor Bybelse hermeneutiek.

- A.D. Pont, in sy ongepubliseerde klasaantekeninge wat in my besit is, verwys in enkele sinne na Ebeling se benadering tot kerkgeskiedenis sonder om dit in detail te bespreek.

- Graham Duncan (2005:58) verwys in 'n enkele sin na Ebeling se standpunte. Duncan fokus op die sendinggeskiedenis en doen gevolglik moeite om in gesprek te tree met Afrika-teoloë soos Kalu, Gundani en veral Maluleke (Duncan 2005:1-4). Hy toon die noodsaak van ' $n$ nuwe benadering aan en praat selfs van ' $n$ old Historiography en 'n new Historiography (Duncan 2005:52).

- Jeremy Punt verwys slegs in 'n voetnoot na Ebeling se benadering tot die kerkgeskiedenis, maar beaam Räisänen se kritiek dat Ebeling die kerkgeskiedenis verkeerdelik as 'n prescriptive discipline beskou het (Punt 2006:892).

- J.P. Labuschagne het in 2008 in ' $n$ artikel in die HTS Teologiese Studies 'n saak daarvoor uitgemaak dat historiese teologie en spesifiek kerkgeskiedenis as teologiegeskiedenis benader moet word. Daarin vind hy aansluiting by Ebeling se latere bydraes. Hy verwys egter nie na Ebeling se Kirchengeschichte als Geschichte der Auslegung der Heiligen Schrift (1947) of sy Geschichtlichkeit der Kirche und ihrer Verkündigung als theologisches Problem 
(1954) nie. Labuschagne kom tot die gevolgtrekking dat Ebeling se benadering tot die kerkgeskiedenis ' $n$ 'nuwe paradigma' verteenwoordig wat bepaalde meriete het, sonder om die praktiese implikasies daarvan uit te spel.

Waarom dus aandag gee aan Gerhard Ebeling se benadering tot die historiese teologie? Ten spyte van die relatiewe min aandag wat Ebeling in die historiese teologie in Suid-Afrika ontvang het, meen ek dat hy ' $n$ paar beginsels aan die orde gestel het waarvan ons deeglik kennis moet neem. Daarbenewens is en bly Gerhard Ebeling ' $n$ uiters bekwame teoloog wat in die teologiegeskiedenis uitstaan, veral ten opsigte van sy bydrae tot die nuwe hermeneutiek en Luthernavorsing. Bo alles was hy 'n teoloog met 'n passie vir die kerk en die verkondiging van die evangelie. Daarom is en bly dit ' $n$ belewenis om met Ebeling in gesprek te tree.

\section{Historisiteit as teologiese probleem ${ }^{3}$}

Ebeling se bydrae tot die historiese teologie moet verstaan word teen die breër agtergrond van die filosofiese en teologiese gesprekke oor menslike bestaan, historisiteit en taal. McGrath (2001:380-405) meen dat die verband tussen geloof en geskiedenis die sentrale teologiese vraagstuk van die twintigste eeu was. Dit is 'n vraagstuk wat steeds op talle aspekte van die teologie bepaalde invloed uitoefen - onder andere die hermeneutiek, histories-kritiese eksegese, die historisiteit van Jesus, God se handelinge in die geskiedenis en God se selfopenbaring in die geskiedenis.

Afgesien van die historisme wat aan die begin van die 20ste eeu nog ' $n$ bepaalde invloed uitgeoefen het (sien Van Niftrik 1948:29-31), het die publikasie van Martin Heidegger se Sein und Zeit ${ }^{4}$ die gesprek oor menslike bestaan en historisiteit in die sentrum van die teologiese debat geplaas. Die eigentliche van die mens is dat hy altyd, deur die geskiedenis heen, op weg is (Dreyer 1974:11-12). Heidegger het die geskiedenis bevry van die subjek-objek skema (Pieterse 1979:29). 'n Historiese dokument dra nie net objektiewe feite oor nie, maar verwoord altyd iets van die menslike eksistensie. Deur historiese dokumente te bestudeer word ' $n$ mens bewus van die verlede-mens se bestaan en dit open nuwe moontlikhede vir die verstaan van die nou-mens se bestaan. Die dieper verstaan van menslike bestaan is voorwaardelik vir die verstaan van historiese tekste.

Heidegger se latere werke fokus meer op die uitlê van tekste (Palmer 1969:141) en taal as die ruimte vir menslike eksistensie. Ons verstaan van die wêreld en waarheid is onskeibaar van taal omdat taal die wesenlike (Sein) openbaar of ontbloot (West 1996:104). Taal transendeer die individuele subjek, individuele bewussyn en bestaan.

Ebeling (1947:9-11) se afwysing van objektiewe historiese kennis (soos Von Ranke se standpunt dat geskiedenis gebeure moet beskryf wie es eigentlich war) en die klem op die 3.Sien in die verband onder andere Ebeling (1954)

4.Heidegger ([1927] 1963). herinterpretasie van tekste sluit aan by Heidegger se verstaan van die geskiedenis en die menslike eksistensie in terme van taal. Breedweg beskou, het die vroeë werk van Heidegger vormend op Ebeling se verstaan van die geskiedenis, taal en hermeneutiek ingewerk.

Ook Rudolf Bultmann het in navolging van Heidegger ' $n$ baie spesifieke geskiedsbeskouing ontwikkel. Bultmann was in Marburg in die periode toe Heidegger aan Sein und Zeit gewerk het. Die ooreenkomste tussen Heidegger en Bultmann is al breedvoerig beskryf (sien Macquarrie 1955). Bultmann volg Heidegger in sy verstaan van taal as iets van persoonlike belang; die gedagte dat God (Sein) die mens as Woord en in taal konfronteer (na analogie van Heidegger wat Sein as taal verstaan) en die kerugma wat die mens in sy historiese en menslike eksistensie aanspreek (Palmer 1969:50). Bultmann se 'ontmitologisering' beklemtoon die transformasie in die verstaan van menslike eksistensie (Palmer 1969:48).

Later, in sy Gifford Lectures (Bultmann 1955), het Bultmann sy konsep van die geskiedenis en die eskatologie verder uitgewerk. Daarin word dit duidelik dat twee fundamentele vrae op die tafel is: Hoe moet historiese dokumente wat binne ' $n$ bepaalde tradisie ontwikkel verstaan word (Bultmann 1955:6-7) en wat is die aard of wese van historiese kennis (Bultmann 1955:110 ev.)? In die gedeelte spreek hy ook die vraag na die objektiwiteit van historiese kennis aan.

Ebeling plaas soos Bultmann die hermeneutiese vraag in die middelpunt van sy denke (Palmer 1969:52). Daarom is dit vanselfsprekend dat Ebeling ook die historiese teologie (en kerkgeskiedenis) as 'n geskiedenis van Skrifuitleg beskou. Hy beklemtoon die betekenis van tekste, in teenstelling met 'n histories-feitelike verstaan van tekste. Hy voer die gedagte verder deur taal (en die verkondiging) as 'gebeure' te verstaan (Palmer 1969:53). Dit het 'n fundamentele invloed op die nuwe homiletiek uitgeoefen. Tydens elke erediens en elke preek gebeur die Woord opnuut. Die Woord gebeur egter nie net in die erediens nie, maar in die teologiese arbeid, kerkregering, barmhartigheidsdiens, sending en elke ander aksie van die gemeente in die wêreld - selfs waar daar oorlog gemaak word in die naam van God (Ebeling 1947:24).

Uit hierdie hermeneutiese benadering van Ebeling tot die teologie vind ons nie net die invloede van Heidegger en Bultmann nie, maar is daar ook ' $n$ besorgde pastor aan die woord. Ebeling worstel met die vraag hoe die evangelie in elke nuwe konteks die hoorders kan aanspreek (Thiselton 1979:308). Wanneer die historiese teologie die uitleg van die Skrif histories ondersoek, word dit diensbaar aan die kerklike verkondiging.

Ebeling het ook deeglik kennis geneem van die werk van Karl Barth (Ebeling 1947:6). In aansluiting by Kierkegaard het Barth in sy Römerbrief ([1919] 1963) gewys op die dialektiese spanning tussen tyd en ewigheid, of anders, tussen mens en God (McGrath 2001:107). Daarin verwoord Barth die geskiedenis as ' $n$ gesprek tussen verlede en hede, 
ein fortgesetzes, immer ausrichtigeres und eindringenderes Gespräch zwischen der Weisheit von gestern und der Weisheit von morgen, die eine und dieselbe ist (Barth [1919] 1963:v).

Dit was veral Barth se verstaan van die eie aard van teologieas-wetenskap wat 'n invloed op Ebeling uitgeoefen het. In 1932 verskyn die eerste band van Barth se Kircliche Dogmatik (Barth 1932). Daarin (KD I/1/1) skryf hy:

Dogmatik ist als theologische Disziplin die wissenschaftliche Selbstprüfung der christlichen Kirche hinsichtlich des Inhalts der ihr eigentümlichen Rede von Gott ... Die Kirche bekennt sich zu Gott, indem sie von Gott redet. Das geschieht einmal durch ihre Existenz im Handeln jedes einzelnen Glaubenden. Und das geschieht zweitens durch ihr besonderes Handeln als Gemeinschaft: in der Verkündigung durch Predigt und Sakramentsverwaltung, in der Anbetung, im Unterricht, in der äußeren und inneren Mission mit Einschluß der Liebestätigkeit unter den Schwachen, Kranken und Gefährdeten. (Barth 1932)

In Barth se definisie van die aard en opdrag van die teologie word die kerklike verkondiging en die uitleg van die Skrif sentraal gestel. Volgens Barth behoort die teologiese nadenke nie sy vertrekpunt in menslike religieuse behoeftes of die geskiedenis te vind nie, maar in God self en in die feit dat God kies om Homself in en deur die Woord aan die mens te openbaar. Barth verstaan die Woord as die vleesgeworde Woord, die Skrif en die verkondigde Woord. Die sentraliteit van die Woord en die verkondiging in Barth se teologie is duidelik. Ook in Ebeling se teologie gaan dit om Skrifuitleg en die verkondiging van die Woord, waartoe die historiese teologie diensbaar moet wees.

Emil Brunner, Ebeling se voorganger in Zürich, het in 1953 Das Ewige als Zukunft und Gegenwart gepubliseer. Daarin (Brunner 1953:46-64) behandel hy onder meer die Christelike verstaan van tyd en ewigheid. Agter die probleem van die geskiedenis staan die fundamentele vraag na die wese van tyd, wat hy bespreek met verwysing na Heidegger se filosofiese en Einstein se natuurwetenskaplike verstaan van tyd. Hy verwys ook na Oscar Cullmann, wat in 1946 sy bekende Christus und die Zeit (Cullmann [1946] 1962) gepubliseer het. Daarin behandel hy die vroeë Christelike verstaan van die geskiedenis en tyd aan die hand van die heilsgeskiedenis.

Brunner (1953:65) beskryf die kerk as 'n geloofsgemeenskap wat in die Messiaans-eskatalogiese hede onder leiding van die Heilige Gees leef met die opdrag om die Woord te verkondig. In die geloof word die toekomstige dinge teenswoordige dinge. Brunner tree ook in 'n kritiese gesprek met Barth en Bultmann, waarin hy met groot respek bepaalde standpunte afwys, maar tegelykertyd beklemtoon dat hy homself en Bultmann as mitarbeitern Karl Barth's in weiteren Sinne beskou (Brunner 1953:231). Gemeenskaplik aan Bultmann, Barth en Brunner is die fokus op die verkondiging en die hoop wat dit bring.

Ebeling het regdeur sy loopbaan aandag gegee aan die verband tussen geloof en geskiedenis, teologie en realiteit, die Bybel as historiese narratief en die onderskeid tussen Historie en Geschichte (Ebeling 1947:12), onder andere in lesings wat hy deur die loop van 1958 en 1959 aan die Universiteit van Zürich gelewer het (Ebeling 1963:7). Hierop word nie verder ingegaan nie. Dit is die problematiek waaraan aandag gegee word in ' $n$ inleiding tot die historiese teologie.

\section{Die kerkgeskiedenis as geskiedenis van Skrifuitleg: enkele beginsels}

Gerhard Ebeling (1912-2001) kom uit die dampkring van die dialektiese teologie. Soos reeds hierbo genoem, was sy leermeesters onder andere Barth, Bonhoeffer, Brunner en Bultmann. Tydens die Tweede Wêreldoorlog het hy in die Mediese Korps in Berlyn diens gedoen. In dié tyd bedien hy ook ' $\mathrm{n}$ gemeente van die Bekennenden Kirche (Menacher 2013:313). As gevolg van sy deelname aan die Kirchenkampf is sy huis gereeld deur die Nazi's deursoek. Ten spyte daarvan word sy proefskrif in 1942 gepubliseer. Na die Tweede Wêreldoorlog is Ebeling as dosent in kerkgeskiedenis aan die Universiteit van Tübingen aangestel. In 1954 volg hy Helmut Thielicke as dosent in sistematiese teologie op. Oor 'n periode van bykans dertig jaar doseer hy afwisselend aan die Universiteite van Zürich en Tübingen.

Kort na sy aanstelling as dosent in die kerkgeskiedenis het Ebeling sy Kirchengeschichte als Geschichte der Auslegung der Heiligen Schrift gepubliseer (Ebeling 1947) waarin hy enkele beginsels vir die beoefening van kerkgeskiedenis bespreek.

Ebeling (1947:24) beklemtoon dat dit die kerk se verantwoordelikheid is om die Bybel te interpreteer en aan alle mense te verkondig (Auslegung der Heiligen Schrift volzieht sich in Kultus und Gebet ...). Die kerk is daarvoor verantwoordelik om die oorspronklike Christelike boodskap op so 'n wyse uit te lê en te verkondig dat die oorspronklike woordgebeure opnuut gebeur. Teologiese nadenke en gesprek dien die verkondiging van die kerk. Wanneer die kerkgeskiedenis sigself met die geskiedenis van Skrifuitleg besig hou, word dit diensbaar aan die verkondiging van die kerk. Dit beteken, myns insiens, dat die teologie nie in die eerste plek ' $n$ aktiwiteit is wat aan universiteite voltrek word nie, maar in die kerk, ten dienste van die erediens en die kerklike verkondiging. Die natuurlike habitat van die teologie as spreke oor God is primêr die kerk en sekondêr die teologiese fakulteit of seminarium. Die teologie as nadenke en spreke oor God sal bly voortbestaan met of sonder die inset van ' $n$ universiteit, net soos die beeldende kunste, poësie en musiek sal voortbestaan selfs al sou dit nie meer aan 'n universiteit gedoseer word nie.

Vir Ebeling (1947:4-5) is dit vanselfsprekend dat kerkgeskiedenis onverkort as teologiese dissipline beskou moet word. Hy bepleit meer gesprek tussen die verskillende teologiese dissiplines). Die silo's waarbinne die onderskeie teologiese dissiplines funksioneer, moet bevraagteken word, 
want dit belemmer ... die Begegnung der Ganzheit der Theologie mit der Ganzheit der Existenz des heutigen Menschen (Ebeling 1947:7-8). Die eksegetiese en sistematiese teologie het insigte vanuit die kerkgeskiedenis nodig, maar ook omgekeerd. Die teologie baat in die algemeen by verantwoordbare en grondige beoefening van die kerkgeskiedenis (Ebeling 1947:6-7), en alle teologiese arbeid (insluitend die kerkgeskiedenis) moet diensbaar wees aan die uitleg en die verkondiging van die Heilige Skrif (Ebeling 1947:8).

Benewens die feit dat die kerkgeskiedenis 'n onontbeerlike deel van die teologie is, meen Ebeling (1947:3-4) dat die kerkgeskiedenis ook binne die breër verband van historiografie en filosofie van die geskiedenis beoefen moet word. In die Suid-Afrikaanse historiografie is dit onder andere P.S. Dreyer (1974) se Inleiding tot die filosofie van die geskiedenis wat van belang is en steeds bruikbaar is. Die kerkgeskiedenis moet ook as ' $n$ gespesialiseerde onderafdeling van geskiedenis-as-wetenskap beskou word (Ebeling 1947:8). Dit beteken dat die kerkgeskiedenis aan algemene metodologiese en historiografiese vereistes moet voldoen, onder andere die ontsluiting, interpretasie en beskrywing van primêre bronne.

Daar bestaan geen universele metodologie vir alle wetenskappe wat absolute waarheid waarborg nie (Ebeling 1947:9) Dit is onmoontlik om tot absolute kennis van die geskiedenis te kom. Die verlede is altyd 'n geïnterpreteerde verlede. Daar bestaan altyd 'n dialektiese spanning (Ebeling 1947:10-11) tussen die objektiewe gebeure van die verlede (geskiedenis) en die subjektiewe verstaan van dieselfde gebeure (hermeneutiek). Juis daarom moet die kerkgeskiedenis kritiese wetenskap wees waarin die bronne en die interpretasie van bronne voortdurend 'gereinig' word van ideologie, apologetiek en subjektivisme. Daarom is die kerkgeskiedenis per definisie nooit afgesluit nie. Die voorveronderstellings waarmee die kerkgeskiedenis beoefen word, moet voortdurend getoets word. Dit beteken nie dat die kerkgeskiedenis standtpunktlos und unperspektivisch (Ebeling 1947:11) beoefen word nie. ${ }^{5}$

Hoewel die kerkgeskiedenis met die insigte en eise van die historiografie erns maak, is daar ook duidelike verskille tussen kerkgeskiedenis en die profane beofening van geskiedenis-as-wetenskap: Die historisiteit en eenmaligheid van Jesus Christus se lyding, sterwe en opstanding is die bestaansgrond virdieChristelikegeloofengeskiedsbeskouing. Sedert Augustinus se De Civitate Dei bestaan die oortuiging dat die menslike bestaan ' $n$ begin en einde het, dat daar ' $n$ stuwende voortgang in die geskiedenis is (Ebeling 1947:14). Hierdie geskiedsbeskouing vloei voort uit Augustinus se omvattende verstaan van die geskiedenis, tyd, eskatologie, ewigheid en geskiedenis (sien Van Oordt 2012). Ebeling (1947:15-16) kritiseer wel Augustinus se dualistiese onderskeid tussen die civitas Dei en die civitas terrena. Daar is nie twee geskiedenisse nie. Teologies gesproke werk God orals en altyd, hoewel God Homself nie orals openbaar nie. Inteendeel: God se teenwoordigheid in die wêreld is dikwels verborge en onsigbaar. Ebeling is van mening dat die 5.Sien Dreyer (2001).
Goddelike 'ja' en 'nee', of anders die Goddelike genade en oordeel, nêrens uit die geskiedenis afleesbaar is nie. God openbaar Hom in en deur Jesus Christus, in die vleesgeworde en verkondigde Woord. Die verkondiging vind in die geskiedenis plaas, maar kan nie uit die geskiedenis afgelees word nie. Die kerkgeskiedenis kan nie deur middel van wetenskaplike studie die spore van God se oordeel of genade in die geskiedenis ontdek nie. Hierin wys Ebeling (op voetspoor van Karl Barth) die standpunt van Ernst Troeltsch en die historisme af, wat van mening was dat geskiedenis opsigself God openbaar (Van Niftrik 1948:29).

Ebeling (1947:17) toon aan dat kerkbegrip bepalend is vir die wyse waarop die kerkgeskiedenis beoefen word. Hy onderskei drie groot tradisies, te wete Rooms-Katoliek, Reformatories en Pentekostalisties (schwärmerische). Wat die reformatoriese kerkbegrip betref, wys Ebeling (1947:19) daarop dat die dialektiese spanning in die formule 'sigbareonsigbare kerk' problematies bly, veral ten opsigte van die verhouding kerk en geskiedenis.

Ebeling is van mening dat die diversiteit en geskakeerdheid van plaaslike geloofsgemeenskappe dit onmoontlik maak om 'n algemene kerkgeskiedenis te skryf (Ebeling 1947:20). Die kerkgeskiedenis moet eerder verstaan word as Geschichte der Auslegung der Heiligen Schrift (Ebeling 1947:22). Die opdrag van die kerkgeskiedenis is nie om eksegese van die Heilige Skrif te doen nie (dit is die opdrag van Ou en Nuwe Testament), maar eerder om vas te stel hoedat die kerk vanaf die Pinkstergebeure en regdeur die geskiedenis die Skrif geïnterpreteer en verkondig het. Só gesien, staan die kerkgeskiedenis in diens van die eksegese, prediking, erediens en kerklike orde (Ebeling 1947:24). Volgens Ebeling (1947:22-28) help hierdie definisie om die grense, wese en teologiese karakter van die kerkgeskiedenis te bepaal.

\section{Historiese teologie: inhoud en struktuur Indeling}

Die kerkgeskiedenis is tradisioneel in vier hoofperiodes ingedeel, te wete Vroeë Kerk, Middeleeue, Reformasie en die Moderne Periode. Voorbeelde hiervan is te vind in Bakhuizen van den Brink (1980) se Kerkgeschiedenis, Reventlow (2009) se vierdelige indeling in sy Epochen von Bibelauslegung en McGrath (2013) se indeling in sy Historical theology.

Die indeling van historiese teologie gaan egter om meer as periodisering. Die belangrike vraag op die tafel is die inhoudelike of onderafdelings wat deel uitmaak van die historiese teologie. Daaroor bestaan uiteenlopende standpunte en menings. Inhoude word dikwels deur praktiese of didaktiese oorwegings bepaal, byvoorbeeld die wyse waarop die kurrikulum saamgestel word en hoe die verskillende teologiese dissiplines in departemente verdeel word. Dit word al meer gebruiklik om alles wat met geskiedenis of kerklike verlede te doen het, om praktiese redes as 'kerkgeskiedenis' te beskou. 
Enige historiese dissipline het met die verlede en die mens-as-geskiedenis te doen. Die historiese teologie het te doen met die kerklike verlede, met die Christelike geloof wat in die geskiedenis en in die werklikheid van menslike bestaan tot uitdrukking kom. Die verlede kan nie tot ' $n$ enkele kerk of groot historiese gebeure beperk word nie. Kerklike belydenis, verkondiging, getuienis, dienswerk, teologie en uitbreiding is onder andere deel van die kerk se geskiedenis.

Na my mening kan diehistoriese teologiein vyfonderafdelings ingedeel word, te wete inleiding tot die historiese teologie, kerkgeskiedenis, teologiegeskiedenis, sendinggeskiedenis en kerkreg. Juis dít maak die skopus van die historiese teologie buitengewoon omvangryk, wat noodwendig spesialisasie verg (Vosloo 2009:56-57). Vervolgens word die vyf onderafdelings kortliks (en voorlopig) aan die orde gestel.

\section{Inleiding tot die historiese teologie}

Wanneer ons ons met die inleidingsvraagstukke ten opsigte van die historiese teologie besig hou, besef 'n mens hoe wyd die vakgebied is. Verskillende benaderings tot die historiese teologie is aantoonbaar, gebou op bepaalde voorveronderstellings, uitkomste of metodologiese beginsels. Daarom is dit behulpsaam om nie net die aard en inhoud van die historiese teologie te probeer peil nie, maar ook vas te stel hoe dit deur die eeue heen beoefen is. Benewens die ondersoek na die herkoms, aard en inhoud daarvan, kom daar in ons prinsipiële besinning oor die historiese teologie veral vier vrae aan die orde:

- Wat is die kerk? Ebeling het beklemtoon dat kerkbegrip van wesenlike belang vir die kerkgeskiedenis is. Die kerkgeskiedenis as teologiese dissipline hou sigself besig met die kerk as Woordgebeure wat in die geskiedenis (verlede, hede en toekoms) konkreet gestalte aanneem. Hierdie 'gestaltes' wat die kerk in die geskiedenis aangeneem het, word op 'n histories-vergelykende wyse beskryf (sien Kärkkäinen 2003), anders as die sistematiese ekklesiologie wat meer op die wesensvrae fokus. In 'n era van interdissiplinariteit kan die wesensvrae egter nie tot die sistematiese teologie beperk word nie. Dit kan met twee eenvoudige voorbeelde geillustreer word: Die geskiedenis van die Duitse kerk voor die Tweede Wêreldoorlog of die geskiedenis van die Afrikaanse kerke in die era van apartheid kan nie na behore geskryf word as die wese van die kerk nie verreken word of sonder dat kerkhistorici ' $n$ kritiese stem laat hoor nie. Die historiese teologie (en die kerkgeskiedenis spesifiek) is nie net deskriptief van aard nie, maar ook inherent hermeneuties en krities van aard. Historiese teologie is kritiese teologie en nie ' $n$ blote repetisie of beskrywing van dit wat in die verlede gesê is nie (Ebeling 1947:9-11).

- Wat is geskiedenis? Dit is noodsaaklik dat elke historikus rekenskap gee van wat geskiedenis per se is. Hierin word aandag gegee aan die vrae wat vanuit die filosofie van die geskiedenis aan die orde gestel word, maar ook vanuit 'n teologiese perspektief. Die vraag na geskiedenis en eskatologie, tyd en ewigheid, die sin van die geskiedenis en die Christelike hoop is wesenlik deel van kerkhistoriese refleksie (vgl. in die verband Berkhof 1958; Brunner 1953; Bultmann 1955; Cullmann [1946] 1962, 1965; Dreyer 1974; Ebeling 1954; Van Oordt 2012).

- Wat is die objek en metode van die historiese teologie? In hierdie afdeling word vrae aan die orde gestel wat reeds in 'n vorige artikel uiteengesit is (vgl. Dreyer 2001). Dit vereis 'n deeglike begrip van die hermeneutiek, koherensie, korrespondensie, objektiwiteit, subjektiwiteit en singewing.

- Wat is die verband tussen die historiese teologie en ander verwante dissiplines? Die verhouding met ander teologiese dissiplines, veral met die oog op die dosering daarvan, moet duidelik omskryf word. As uitgangspunt dien Ebeling se standpunt dat ' $n$ multidissiplinêre benadering van groot waarde is. Daarbenewens is dit belangrik dat ' $n$ multidissiplinêre benadering ook rekening hou met nieteologiese vakke soos die geskiedenis, sosiologie en regsgeleerdheid.

\section{Die kerkgeskiedenis}

In hierdie onderafdeling van die historiese teologie word die geskiedenis van spesifieke kerke aan die orde gestel. 'Kerkgeskiedenis' verwys dus na die geskiedenis van 'n spesifieke gemeente, kerk of kerklike tradisie wat op grond van bepaalde bronne beskryf word. In 'n veelkerklike of ekumeniese opset, soos tans aan Suid-Afrikaanse universiteite die geval is, skep dit die ruimte vir elke student om navorsing te doen oor sy eie kerklike tradisie of kerk.

Die kerkgeskiedenis handel egter nie net oor die geskiedenis van 'n spesifieke kerk nie. Daar is tans 'n beweging om op randfigure, gewone mense, orale geskiedenis, spesifieke geografiese areas en periodes te fokus, die sogenaamde history from below (sien Vosloo 2009:59-60). Dit is nie net die 'groot' verhale wat belangrik is nie, maar ook die 'klein' verhale.

Ebeling (1947:20) is van mening dat ' $\mathrm{n}$ 'algemene kerkgeskiedenis' per definisie onmoontlik is. Dit beteken egter nie dat 'n omvattende 'geskiedenis van die Christendom', byvoorbeeld Latourette (1964) se A history of Christianity wat 1513 bladsye beslaan, nie van waarde is nie. Inteendeel: Elke student van die kerkgeskiedenis behoort nie net in diepte na die geskiedenis van die kerk te kyk nie, maar ook wyd. Dit is veral op voorgraadse vlak waar ' $n$ meer algemene benadering van toepassing is. In die verlede is algemene kerkgeskiedenis veral op voorgraadse vlak aan studente voorgeskryf.

\section{Die teologiegeskiedenis}

Soos aangetoon, is Ebeling van mening dat ' $\mathrm{n}$ 'algemene kerkgeskiedenis' per definisie onmoontlik is en dat die kerkgeskiedenis eerder op die geskiedenis van Skrifuitleg moet fokus. Die geskiedenis van Skrifuitleg is na my mening sinoniem met die teologiegeskiedenis en selfs dogmengeskiedenis. Persoonlik verkies ek om te praat van 
'teologiegeskiedenis' omdat die geskiedenis van Skrifuitleg na vore kom in die manier hoe teoloë, veral vanuit 'n Bybels-reformatoriese tradisie, met die Skrif omgaan. 'n Klassieke voorbeeld vind ons in die sestiende eeu tydens die Kerkhervorming: Kerklike transformasie het plaasgevind omdat teologie op ' $n$ nuwe wyse beoefen is. Beukes (2008) en Van Aarde (2013) se beskrywing van verskillende modaliteite en teologiese denkrigtings is ' $n$ goeie voorbeeld van teologiegeskiedenis, waar die wyse waarop die Skrif verstaan word en teologie beoefen word 'n direkte effek op kerklike gebeure gehad het.

Wat inhoud betref, bestudeer die teologiegeskiedenis (1) die lewe, teologiese arbeid en bydrae van individuele teoloë, (2) teologiese denkrigtings en tendense en (3) teologiese en leerstellige uitsprake van die kerk.

In teologiegeskiedenis moet noodwendig bepaalde keuses gemaak word. 'n Belangrike kriterium om vir sekere teoloë of teologiese denkrigtings te kies, is die mate waartoe dit die gang van die kerklike geskiedenis beïnvloed het. Invloedryke en belangrike teoloë word oor die algemeen as sodanig beskou omdat hulle ' $n$ wesenlik rol in die geskiedenis gespeel het (bv. Augustinus, Aquinas, Luther, Calvyn, Barth).

Die verwoording van die Christelike geloof en kerklike leer in belydenisse en belydenisskrifte is van groot belang vir die teologiegeskiedenis. Dit hou verband met individuele teoloë se insigte - byvoorbeeld die invloed van Athanasius op die formulerings van die Niceense Belydenis of Calvyn se invloed op die Franse Geloofsbelydenis (1559) en Nederlandse Geloofsbelydenis (1561). Sedert die vroegste kerk is die suiwer geloof, leer en lewe vir die kerk van die uiterste belang en die teologiegeskiedenis fasiliteer die geloofsgesprek deur die insigte van die vaders en moeders van die verlede vir die geloofskinders van vandag te ontsluit en oor te lewer.

\section{Die sendinggeskiedenis}

Vanselfsprekend het die sendinggeskiedenis te doen met verskillende sendingbewegings en die verbreiding van die kerk sedert die tyd van Christus. Die groei van die vroeë kerk, die kerstening van Europa en ander kontinente, die sendingbeweging van die negentiende eeu, die invloed van die missio Dei beginsel en die ekumeniese beweging in die twintigste eeu is alles voorbeelde van sendinggeskiedenis wat ten nouste met kerkgeskiedenis en teologiegeskiedenis verband hou.

Dit gaan egter om meer as 'n beskrywing van bepaalde sendingaksies. Wanneer die kerk vanuit die missio Dei verstaan word, is die geskiedenis van die kerk tegelykertyd die geskiedenis van sending, of anders, God se handelinge met die wêreld. Die 'sendingaktiwiteite' van die kerk is nie die missio Dei nie. Missio Dei is 'n attribuut van die God wat kies om Homself met sy skepping en met die mens besig te hou (Bosch [1991] 2006:390). Daar is 'n onlosmaaklike band tussen die wese van die kerk en die roeping van die kerk. Wie ook al die kerk en die geskiedenis van die kerk bestudeer, moet tegelykertyd aandag gee aan die geskiedenis van die kerklike verkondiging (Ebeling) in die wêreld en die groei van die kerk.

Aan die begin van die een en twintigste eeu is dit nie net die groei van die kerk wat ter sprake is nie, maar ook die agteruitgang van die kerk. Die era van die Christendom is finaal verby. Sedert die Verligting het kerke in Wes-Europa stelselmatig agteruit gegaan. Tans ervaar kerke wêreldwyd enorme druk as gevolg van sosiale verandering. Die kerk word toenemend gemarginaliseer en kerkverlating is ' $n$ algemene verskynsel (Van't Spijker 1990:507-508). Dit stel besondere eise aan historici om dit wat in die samelewing gebeur met kerklike prosesse en die resente geskiedenis in verband te bring. Die historiese teologie (en spesifiek die sendinggeskiedenis) kan ten dienste van die kerklike verkondiging wees wanneer daar op 'n wetenskaplike wyse, met behulp van verskillende vakwetenskappe, oor kerkwees in die een en twintigste eeu navorsing gedoen word. Historici is by uitstek toegerus om die veranderende kerklike en sosiale konteks te interpreteer en daardeur die kerk tot hulp te wees.

\section{Die kerkreg}

Die kerkreg is ' $n$ teologiese dissipline wat bou op die ekklesiologie en ' $n$ bepaalde teologiese visie van die kerk (Koffeman 2009:11). Die kerkreg is ook ingebed in 'n bepaalde kerklike tradisie en geskiedenis (Van Wyk 1992:294). Wanneer die kerklike reg as ius constitutum bestudeer word, kom die kerklike verlede, maar ook die huidige konteks en werklikhede, met eens ter sprake. Prakties gesproke: Dit is nie moontlik om vir ' $n$ kerk wat in ' $n$ reformatoriese en Calvinistiese tradisie staan 'n kerkorde te skryf sonder ' $n$ deeglike historiese kennis van die sestiende-eeuse kerkordes nie. Dit is waar van elke kerklike tradisie. Die kerkreg moet verder rekening hou met insigte vanuit die Ou en Nuwe Testament asook die sistematiese teologie. Ook die belydenisskrifte is ter sake - gevolglik is kerkreg ten diepste 'n teologiese dissipline wat interdissiplinêr funksioneer.

Die belang van die ekklesiologie vir die kerkreg kan nie oorbeklemtoon word nie. Deur die loop van die geskiedenis het die liggaam van Christus op uiteenlopende wyses sigbaar geword. Die kerk het in verskillende tye en plekke 'n proses van institusionalisering ondergaan. 'n Historiesvergelykende ekklesiologie bestudeer hierdie prosesse en hoe die kerk deur die geskiedenis konkreet gestalte aangeneem het. Dit bied verdere teologiese onderbou vir die daarstel van kerkordes.

\section{Slot}

In ons nadenke oor historiese teologie moet ons ten slotte in gedagte hou dat die historiografie sigself in 'n periode van reoriëntasie en die vestiging van nuwe metodologiese benaderings bevind. Gabrielle Spiegel (2014:149-179), verbonde aan die Johns Hopkins Universiteit, bespreek in 'n resente artikel die verskuiwings wat die afgelope dekade in historiografie plaasgevind het. Die sogenaamde linguistic turn (sien Surkis 2012) in die periode na die Tweede 
Wêreldoorlog het plek gemaak vir verskeie nuwe fokus areas in historiese navorsing. Daar is tans toenemende fokus op sosiale analise, die rol van die individu as agent van sosiale verandering, ' $\mathrm{n}$ herontdekking van empiriese (feitelike) navorsing, kwantitatiewe analise, die effek van digitalisering op die sosiale bewussyn, die verband tussen geheue (memory) en geskiedenis en mondelingse getuienis as deel van herstelprosesse in verskillende dele van die wêreld deur middel van Waarheid- en Versoeningskommissies, waarvan die Suid-Afrikaanse WVK 'n uitstaande voorbeeld is (Spiegel 2014:166-168). Die historiografie vertoon tans verstommende diversiteit en uiteenlopende benaderings, wat in die toekoms tot groter diversiteit in die historiese teologie kan lei.

Indien die historiese teologie op 'n sinvolle wyse aangebied word, lewer dit 'n belangrike bydrae tot die teologiese gesprek en die opleiding van predikante. Dit verbreed en verdiep teologiese kennis en help die kerk om met insig en onderskeidingsvermoë eietydse uitdagings te konfronteer. Dit fasiliteer ' $\mathrm{n}$ gefundeerde proses van transformasie en kerkhervorming.

Ten slotte: ' $\mathrm{n}$ Kerk en teologie sonder ' $\mathrm{n}$ verlede is soos 'n mens wat aan geheueverlies ly, wat sonder identiteit al struikelend en bevrees die toekoms ingaan.

\section{Erkenning Mededingende belange}

Die outeur verklaar hiermee dat hy geen finansiële of persoonlike verbintenis het met enige party wat hom nadelig of voordelig kon beïnvloed het in die skryf van hierdie artikel nie.

\section{Literatuurverwysings}

Afrikaanse Woordelys en Spelreels 9.65 besigtig op 10 September 2015 by http:// www.oocities.org/afrikaanse_spelreels/09hoofletters.html

Bakhuizen van den Brink, J.N., 1980, Handboek der kerkgeschiedenis, Dele I-IV, De Tille B.V., Leeuwarden.

Barth, K., [1919] 1963, Der Römerbrief, EVZ-Verlag, Zürich.

Barth, K., 1932, Kirchliche Dogmatik I/1, Evangelische Verlag A.G., Zollikon, Zürich.

Berkhof, H., 1958, Christus de zin der geshiedenis, G.F. Callenbach N.V., Nijkerk.

Beukes, J., 2008, 'Voices carry: An archaeology of the Hervormd approach', HTS Teologiese Studies/Theological Studies 64(1), 73-109. http://dx.doi.org/10.4102/ hts.v64i1.4

Black, D.A., 2014, 'Indoctrination to indifference?: Perceptions of South African secondary school history education, with special reference to Mpumalanga, 1960-2012', PhD thesis, Department of History, University of South Africa.

Bosch, D.J., [1991] 2006, Transforming mission: Paradigm shifts in theology of mission, Orbis Books, New York.

Bromiley, G.W., 1978, Historical theology: An introduction, Wm. B. Eerdmans Publishing Co., Grand Rapids, MI.

Brunner, E., 1953, Das Ewige als Zukunft und Gegenwart, Zwingli-Verlag, Zürich.

Bultmann, R., 1955, The presence of eternity: History and eschatology, The Gifford Lectures 1955, Harper \& Brothers, New York.

Cullmann, O., [1946] 1962, Christus und die Zeit: Die Urchristliche Zeit- und Geschichtsauffassung, Derde Dritte Auflage, EVZ-Verlag, Zürich.

Cullmann, O., 1965, Heil als Geschichte: Heilsgeschichtliche Existenz im Neuen Testament, J.C.B. Mohr (Paul Siebeck), Tübingen.

Denis, P., 1997, 'From church history to religious history: Strengths and weaknesses of South African religious historiography', Journal of Theology for Southern Africa 99, 84-93.
Dreyer, P.S., 1974, Inleiding tot die filosofie van die geskiedenis, HAUM Uitgewers, Kaapstad, Pretoria.

Dreyer, W.A., 2001, 'Kerkgeskiedenis: Perspektiewe vanuit die Nederduitsch Hervormde Kerk van Afrika', HTS Teologiese Studies 57(3/4), 1015-1036. http:// dx.doi.org/10.4102/hts.v57i3/4.1864

Duncan, G., 2005, 'Historiography and ideology in the (mission) history of Christianity in Africa', Studia Historiae Ecclesiasticae XXXI(1), 51-69.

Ebeling, G., 1947, Kirchengeschichte als Geschichte der Auslegung der Heiligen Schrift, Verlag von J.C.B. Mohr (Paul Siebeck), Tübingen.

Ebeling, G., 1954, Die Geschichtlichkeit der Kirche und ihrer Verkündigung als theologisches problem, J.C.B. Mohr (Paul Siebeck), Tübingen.

Ebeling, G., 1963, Christelijk Geloof, vert. M.M. van Hengel-Baaw, W. Ten Have N.V., Amsterdam.

González, J.L., 2002, The changing shape of church history, Chalice Press, St. Louis.

Heidegger, M., [1927] 1963, Sein und Zeit, 7de uitg., Niemeyer, Tübingen.

Kärkkäinen, V.-M., 2003, An introduction to ecclesiology: Ecumenical, historical and global perspectives, InterVarsity Press, Downers Grove, IL.

Koffeman, L.J., 2009, Het goed recht van de kerk: Een theologische inleiding op het kerkrecht, Uitgeverij Kok, Kampen.

Labuschagne, J.P., 2008, 'Die hermeneutiekvankerkgeskiedenis en “teologiegeskiedenis" 'n "Nuwe pardigma" vir kerkgeskiedenis', HTS Teologiese Studies 64(2), 861-883. http://dx.doi.org/10.4102/hts.v64i2.48

Latourette, K.S., 1964, A history of Christianity, Eyre and Spottingswoode Limited, London.

Macquarrie, J., 1955, An extentialist theology: A comparison of Heidegger and Bultmann, SCM Press, London.

Maluleke, T.S., 1995. "'A morula tree between two fields": The commentary of selected Tsonga writings on mission Christianity', DTh thesis, Department of Missiology, UNISA.

McGrath, A.E., 2001, Christian theology: An introduction, 3rd edn., Blackwell Publishing, Oxford.

McGrath, A.E., 2013, Historical theology, 2nd edn., Blackwell Publishers, Oxford.

Menacher, M.D., 2013, 'Gerhard Ebeling 1912-2001', in M.C. Mattes (ed.), Twentieth century Lutheran theologians, pp. 307-334, Vandenhoeck \& Ruprecht, Göttingen.

Palmer, R.E., 1969, Hermeneutics. Interpretation theory in Schleiermacher, Dilthey, Heidegger and Gadamer, Northwestern University Press, Evanston IL.

Pieterse, H.J.C., 1979, Skrifverstaan en prediking, N.G. Kerkboekhandel, Pretoria.

Punt, J., 2006, 'Using the Bible in post-apartheid South Africa: Its influence and impact amidst the gay debate', HTS Teologiese Studies/Theological Studies 62(3) 885-907. http://dx.doi.org/10.4102/hts.v62i3.381

Reventlow, H., 2009, History of Biblical interpretation, vol. I-IV, S. Ackerma \& T. Thatcher (eds.), transl. L.G. Perdue, Society of Biblical Literature (SBL), Atlanta.

Spiegel, G.M., 2014, 'The future of the past: History, memory and the ethical imperatives of writing history', Journal of the Philosophy of History 8, 149-179. $\mathrm{http}: / / d x$.doi.org/10.1163/18722636-12341269

Stoop, J.A.A.A., 1978, 'Kerkgeskiedenis', in I.H. Eybers (red), Inleiding in die Teologie, bl. 149-179, NG Kerkboekhandel, Pretoria.

Surkis, J., 2012, "'When was the linguistic turn? A genealogy": AHR forum on "Historiographic turns in critical perspective",', American Historical Review 117, 700-722. http://dx.doi.org/10.1086/ahr.117.3.700

Thiselton, A.C., 1979, 'The new hermeneutic', in I.H. Marshall (ed.), New Testament interpretation, pp. 308-333, The Paternoster Press, Exeter

Van Aarde, A.G., 2013, " $n$ Postliberale perspektief op 'n ekklesiologiese modaliteit as ' $n$ ecclesiola in ecclesia: ' $n$ Herorientasie in die Nederduitsh Hervormde Kerk van Afrika', HTS Teologiese Studies/Theological Studies 69(1), Art. \#2012, 14 bladsye, http://dx.doi.org/10.4102/hts.v69i1.2012

Van Huyssteen, J.W.V., 1970, Teologie van die rede: Die funksie van die rasionele in die denke van Wolfhart Pannenberg, J.H. Kok N.V., Kampen.

Van Jaarsveld, F.A., 1953, Van apologetiek tot objektiwiteit in ons kerkgeskiedskrywing, Nasionale Handelsdrukkery Beperk, Elsiesrivier.

Van Niftrik, G.C., 1948, Een beroerder Israels: Enkele hoofdgedachten in de theologie van Karl Barth, G.F. Callenbach N.V. Uitgever, Nijkerk.

Van Oordt, J., 2012, 'The end is now: Augustine on history and eschatology', HTS Teologiese Studies/ Theological Studies 68 (1), Art. \# 1188, 7 bladsye, http:/// dx.doi.org/10.4102/hts.v68i1.1188

Van Wyk, B.J., 1992, 'Vyf en sewentig jaar Kerkreg', HTS Hervormde Teologiese Studies 48(1/2), 293-312.

Van't Spijker, W., 1990. 'Uitzicht', in W. van't Spijker (red.), De Kerk: Wezen, weg en werk van die kerk naar reformatorisch opvatting, , Uitgeverij De Groot Goudriaan, Kampen.

Vosloo, R., 2009, 'Quo vadis Church History?: Some theses on the future of church history as an academic theological discipline', Scriptura 100, 54-64. http://dx.doi. org/10.7833/100-0-653

West, D., 1996, An inroduction to continental philosophy, Polity Press, Cambridge. 